\title{
Plant Extracts of Psidium guajava, Mangifera and Mentha sp. inhibit the Growth of the Population of Single-species Oral Biofilm
}

\author{
Wan Nordini Hasnor WI ${ }^{1 *}$, Fathilah $\mathrm{AR}^{2}$ and Rahim $\mathrm{ZHA}^{2}$
}

${ }^{1}$ Faculty of Pharmacy, Universiti Teknologi MARA (Bertam Campus), Penang, Malaysia

${ }^{2}$ Faculty of Dentistry, Department of Oral Biology, University of Malaya, 50603 Kuala Lumpur, Malaysia

\begin{abstract}
The use of oral gargle has gained popularity recently. Despite being either alcohol-based or plant-based, the main purpose for the usage of oral gargle is to prevent the accumulation of heavy plaque or oral malodour, that usually caused by the growth of oral biofilm. In this study, the antimicrobial effect of Psidium guajava, Mangifera sp. and Mentha sp. was tested against the single-species biofilm consisting of Streptococcus sanguinis and Streptococcus mitis. The biofilms were allowed to grow on the saliva-coated glass beads in Nordini's Artificial Mouth (NAM) model to represent the oral cavity for 24 hours. The saliva would form the experimental pellicle on the glass beads. The results obtained showed that biofilm of Streptococcus mitis displayed a maximum adherence $(11.53 \%)$ compared to Streptococcus sanguinis $(1.83 \%)$ on the untreated experimental pellicle. When the aqueous extraction of plant extract was applied on the experimental pellicle, the bacterial adherence was significantly reduced to $1.54 \%$ (Streptococcus mitis) and $0.21 \%$ (Streptococcus sanguinis). This result indicates that the selected plant extracts can be used to inhibit the heavy growth of oral biofilm.
\end{abstract}

Keywords: Plant extracts; Oral biofilm; Streptococcus mitis; Streptococcus sanguinis; Bacterial adherence 2

\section{Introduction}

Psidium guajava (guava), Mangifera sp. (mango) and Mentha sp. (mint) have a long history of traditional uses $[1,2]$ much of which has been validated by scientific research. The guava leaves extract which comes from the family Myrtaceae, was reported to be very effective in inhibiting the growth of Staphylococcus aureus [3] while the guava bark methanolic extract showed a positive antibacterial activity against Bacillus subtilis, Staphylococcus aureus, Escherichia coli and Pseudomonas aeruginosa [4]. In addition, the leaves were also reported to have an anti-adherence effect towards the oral bacteria, especially the early colonizers of dental plaque [5,6]. Mangifera sp. or popularly known as mango, comes from the family Anacardiaceae. The mango tree is not only grown naturally, but is also cultivated mainly in tropical and subtropical regions. The decoction of the leaves functions as antihelmintic and also can be used to gargle in the prevention of halitosis [1]. It was also reported that an ethanolic extract of mango seed kernel possessed an antimicrobial activity against food-borne pathogenic bacteria [7]. In the fourteenth century, mint (Mentha sp.) which comes from the family Labiatae, was used for whitening the teeth, and its distilled oil is still used to flavour tooth-pastes and chewing gum.

Streptococcus sanguinis (Strep. sanguinis) or previously known as Streptococcus sanguis [8] which belongs to the mitis-group [9], is one of the early colonizers of dental plaque [5,10]. Once a tooth erupts into the oral cavity, Strep. sanguinis colonizes its surface. The colonization of Strep. sanguinis to the tooth surfaces begins at the age of nine months in infants and their population was shown to increase with the age of the infants [11,12]. Streptococcus mitis (Strep. mitis) is a common species in the mouth and frequently predominates with Strep. sanguinis during the initial colonization of the tooth surface [10]. Strep. mitis is commonly found on the soft tissues of the cheeks, lips and the ventral surface of the tongue as they tend to adhere to non-keratinized mucosa in the mouth [9]. In an oral cavity, these microbes tend to grow in the form of biofilm. They are arranged in micro colonies and surrounded by protective matrix [13] consisting of extracellular 3 polymers that form a thick, continuous, hydrated, charged layer around the cells $[14,15]$.
The matrix protects the biofilm from host defences [14], desiccation and the action of antimicrobial agents [16]. Throughout the years, many researchers have attempted to study the mechanism of action of plant extracts as antibacterial agents [5,17-23]. However, their research involved mainly microbes growing under the planktonic state, which refers to the bacteria that live as floating organisms in the test tube or flask cultures in the laboratory. Under such condition, the microbes may not best represent those found in dental plaque. Investigation of oral biofilm in vivo however is often made difficult by its heterogeneity, limited access, the existence of variable and uncontrollable oral environments as well as ethical problems [24]. Therefore, there is a need to investigate the effect of the chosen plant extracts on the singlespecies oral biofilm in vitro.

\section{Materials and Methods}

\section{Preparation of plant extracts}

Leaves of mango (Mangifera sp.) (Figure 1) were obtained from Puchong, Selangor and leaves of guava (Psidium sp.) (Figure 2) were obtained from Kota Bharu, Kelantan. Leaves of mint (Mentha sp.) (Figure 3) grown in Cameron Highlands, Pahang were purchased from the local market in Kuala Lumpur. The leaves were oven-dried at $60^{\circ} \mathrm{C}$ for 48 hours until no changes in the weight were observed. The dried leaves were then grounded into powder and used in the preparation of the aqueous extract. One hundred gram of powdered samples prepared from the leaves of Mangifera sp., Mentha sp. and Psidium sp. were

*Corresponding author: Wan Nordini Hasnor Wan Ismail, Faculty of Pharmacy, University of Technology Mara (Bertam Campus), Persiaran Pendidikan Bertam Perdana, 13200 Kepala Batas, Seberang Perai Utara, Penang, Malaysia, Tel : 604 5623589; Fax: 604-5623575; E-mail: nordini.hasnor@ppinang.uitm.edu.my

Received January 14, 2013; Accepted January 29, 2013; Published January 31 , 2013

Citation: Wan Nordini Hasnor WI, Fathilah AR, Rahim ZHA (2013) Plant Extracts of Psidium guajava, Mangifera and Mentha sp. inhibit the Growth of the Population of Single-species Oral Biofilm. Altern Integ Med 2: 102. doi:10.4172/2327-5162.1000102

Copyright: (c) 2013 Wan Nordini Hasnor WI, et al. This is an open-access article distributed under the terms of the Creative Commons Attribution License, which permits unrestricted use, distribution, and reproduction in any medium, provided the original author and source are credited. 
Citation: Wan Nordini Hasnor WI, Fathilah AR, Rahim ZHA (2013) Plant Extracts of Psidium guajava, Mangifera and Mentha sp. inhibit the Growth of the Population of Single-species Oral Biofilm. Altern Integ Med 2: 102. doi:10.4172/2327-5162.1000102

Page 2 of 6

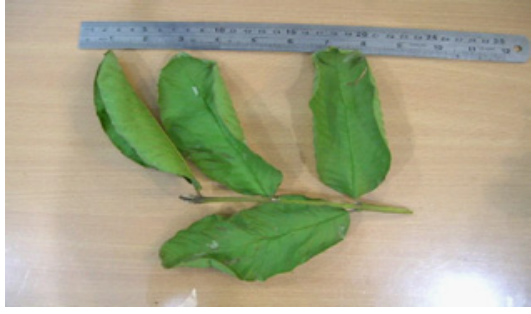

Figure 1: The leaves of Psidium sp.

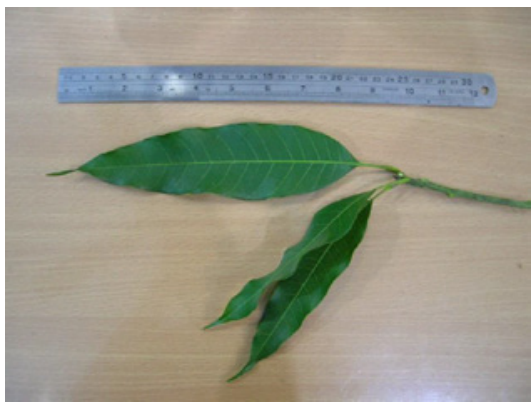

Figure 2: The leaves of Mangifera sp.

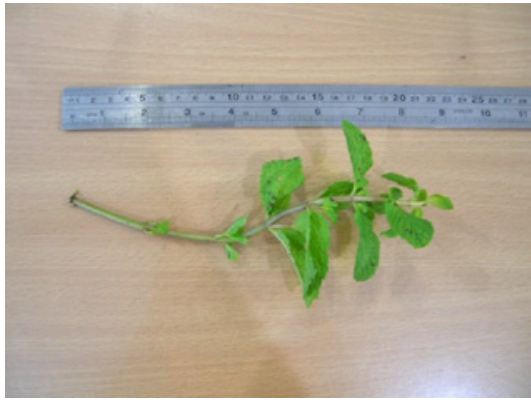

Figure 3: The leaves of Mentha sp.

weighed and put into a large beaker. One thousand $\mathrm{ml}$ of deionised distilled water was added and the mixture was allowed to boil until the final volume became one tenth (1:10) of the original. The debris was then filtered out using filter paper (Whatman No.1, diameter $24 \mathrm{~cm}$ ) with the aid of a suction pump (SPARMAX, Taiwan). One $\mathrm{ml}$ of the clear crude extracts was dispensed into micro centrifuge tubes $(1 \mathrm{ml} /$ tube) and dried using the speed vacuum concentrator (HETO) until no further changes in weight were observed. The dried extracts were then stored at $-20^{\circ} \mathrm{C}$ until further use [25]. Prior to use, all three extracts were diluted with sterile deionised distilled water and mixed to a final concentration of $0.5 \mathrm{mg} / \mathrm{ml}$. All three extracts were combined together before used in the experiment.

\section{NAM model}

The Nordini's Artificial Mouth (NAM) model was used in the study to represent the oral cavity. The model was developed according to the method described earlier [26]. Basically, the model consists of a glass chamber, glass beads, saliva reservoir, bacterial reservoir and peristaltic pump (Figure 4).

\section{Preparation of the glass beads as substratum}

In the study, the glass beads ( $3 \mathrm{~mm}$ diameter) were used to represent the tooth enamel onto which the experimental pellicle and singlespecies biofilm will develop. The glass beads were cleaned and sterilized by autoclaving at $121^{\circ} \mathrm{C}(15$ p.s.i) for 20 minutes. The sterilized glass beads were kept in a sterilized bottle before use.

\section{Preparation of sterile saliva}

Undiluted sterile saliva was prepared according to the method described by De Jong and Van der Hoeven [27]. Approximately $25 \mathrm{ml}$ of stimulated whole saliva (SWS) was collected everyday from a single volunteer to minimize any variations that may arise. The volunteer was asked to chew on a sugar-free gum to stimulate saliva production. The collection of SWS was done using ice-chilled test tubes. The aggregation of protein in the SWS samples was minimized by adding 1,4-DithioD,L-threitol (DTT) to a concentration of $2.5 \mathrm{mM}$. Upon the addition of DTT, the saliva was stirred slowly for 10 mins before it was centrifuged at $864 \mathrm{~g}$ for 30 mins. The supernatant obtained was then filter-sterilized through a disposable $0.2 \mu \mathrm{m}$ (Supor ${ }^{\circledast}$ Membrane) low protein-binding filter (Acrodisc ${ }^{\circledR}$ Syringe Filters, Pall Corp, USA) into sterile test tubes. The sterile SWS was then stored at $-20^{\circ} \mathrm{C}$. Prior to use, the SWS was thawed and centrifuged once again to remove any precipitate.

\section{Preparation of bacterial suspension}

The stock culture of oral bacteria (Strep. mitis and Strept. Sanguinis) were obtained from the Department of Oral Biology, Faculty of Dentistry, University of Malaya. The stock which was kept at $-80^{\circ} \mathrm{C}$ was thawed at room temperature. Each of the thawed stock culture was then inoculated into sterilized BHI broth $(1: 100 \mathrm{v} / \mathrm{v})$ and incubated at $37^{\circ} \mathrm{C}$ for $18-24$ hours. The bacterial suspension was adjusted spectrophotometrically at $550 \mathrm{~nm}$ to 0.144 absorbance which is equivalent to108 cells $/ \mathrm{ml}$ [5]. This procedure is important to standardize the number of cells in the suspension to be used in the study.

\section{The development of experimental pellicle and single-species biofilm in NAM model}

Experimental pellicle: negative-control: The development of experimental pellicle and single-species biofilm (Strep. sanguinis and Strep. mitis) in NAM model was carried out according to the method described by Wan Nordini Hasnor et al. [28]. Ten glass beads were placed in the glass chamber to represent the tooth in the mouth. The glass chamber was then placed in water bath which serves as an incubator to maintain temperature that mimics the human body temperature.

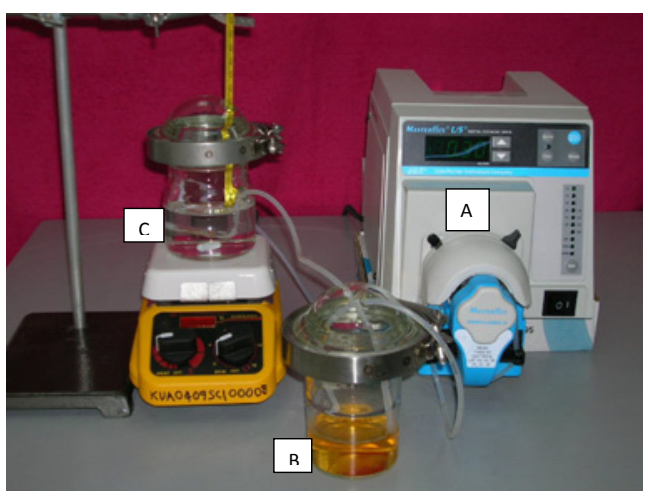

Figure 4: Nordini's Artificial Mouth (NAM) model. This model consists of (A) peristaltic pump; (B) bacterial reservoir; (C) water bath system, which was connecting via rubber tubings. The water bath system houses the glass beads inside the glass chamber. Hot-plate was used to maintain the temperature at $37^{\circ} \mathrm{C}$ 
Citation: Wan Nordini Hasnor WI, Fathilah AR, Rahim ZHA (2013) Plant Extracts of Psidium guajava, Mangifera and Mentha sp. inhibit the Growth of the Population of Single-species Oral Biofilm. Altern Integ Med 2: 102. doi:10.4172/2327-5162.1000102

Page 3 of 6

A sterilized saliva reservoir with a capacity of $50 \mathrm{ml}$ was connected to a peristaltic pump and the NAM model via sterilized rubber tubing. Sterilized saliva was pumped into the NAM model for two minutes at a flow rate of $0.3 \mathrm{ml} / \mathrm{min}$ to coat the glass beads. This was followed by a flow of sterile distilled water to rinse off the excess saliva that remains on the glass beads. The experimental pellicle was now ready to receive bacterial inoculum. Bacterial reservoir which consisted of singlespecies inoculum (Strep. sanguinis and Strep. mitis) $(108 \mathrm{CFU} / \mathrm{ml})$ was pumped into the model at a rate of $0.3 \mathrm{ml} / \mathrm{min}$ and was allowed to form on the glass beads for 24 hours to form a 24 hours biofilm.

Treated experimental pellicle: The steps in the above step i.e. experimental pellicle: negative-control was repeated. After rinsing off the excess saliva on the glass beads with sterile distilled water, a 50 $\mathrm{ml}$ aqueous solution consisted of mixture plant extracts $(0.5 \mathrm{mg} / \mathrm{ml})$ was allowed to flow into the NAM model for two minutes at a rate of $0.3 \mathrm{ml} / \mathrm{min}$. This was followed by a flow of sterile distilled water once again to rinse off the excess extracts on the glass beads. Subsequently, the bacterial inoculum $(108 \mathrm{CFU} / \mathrm{ml})$ was pumped into the model over a period of 24 hours to allow for the formation of a 24 hours singlespecies biofilm on the glass beads. This procedure was repeated by using $0.12 \%$ chlorhexidine (CHX) in place of the plant extracts to serve as a positive-control. The experiment was carried out in triplicates.

\section{The harvesting of the single-species biofilm on the glass beads} and determination of bacterial population

The procedures employed in the harvesting of the single-species biofilm were carried out according to the chart in figure 5. After 24

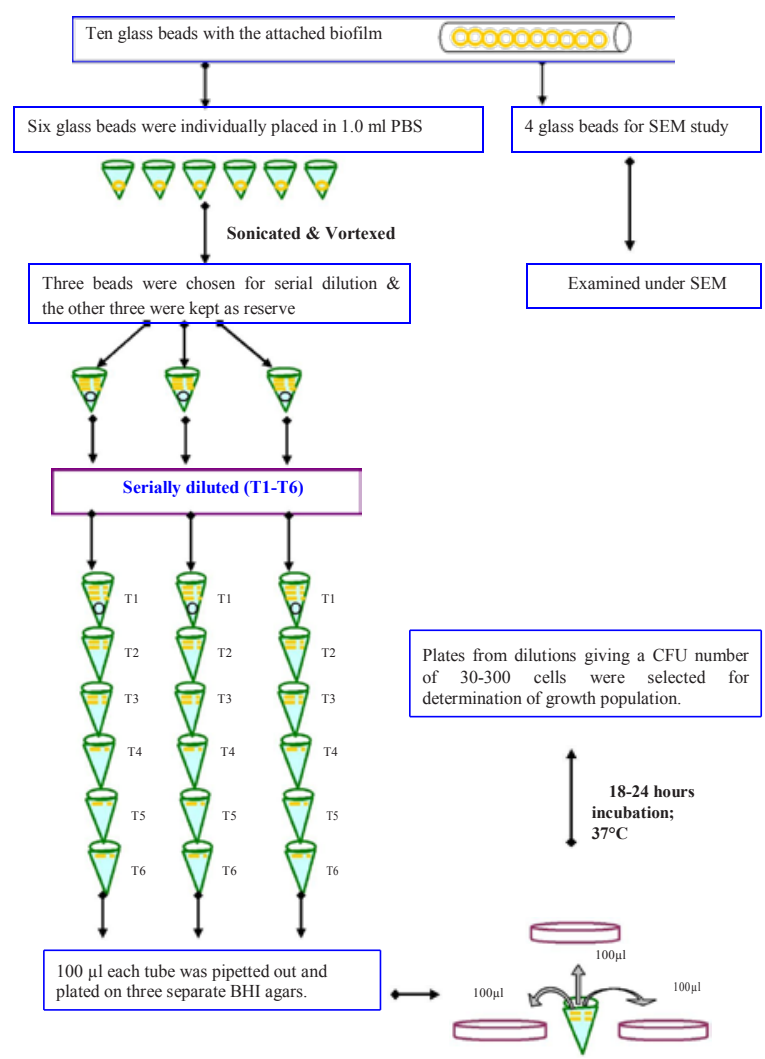

*The experiment was carried out in duplicate. This will give total number of determination $(\mathrm{N})=18$

Figure 5: Schematic chart of the procedures employed in harvesting biofilms from the glass beads. hours, each of the six glass beads with the biofilm formed on them was carefully taken out and placed in the respective micro centrifuge tubes $(1.5 \mathrm{ml})$ containing $1.0 \mathrm{ml}$ of phosphate-buffered saline (PBS). Each of the tubes was sonicated (10 seconds) and vortexed (1 minute) to dislodge any attached bacteria on the glass bead. Each of the tube subsequently containing the bacterial suspension. Out of the six tubes, three were chosen for serial dilution while the other three were kept as reserve. Six serial dilutions of the bacterial suspensions were carried out for each of the tubes. The first serial dilution was referred to as tube 1 (T1) and the sixth serial dilution as tube 6 (T6). A $100 \mu \mathrm{L}$ of each of the serially diluted bacterial suspensions (T1 to T6) was pipetted out and plated on three separate Brain Heart Infusion (BHI) agars. The plates were incubated aerobically at $37^{\circ} \mathrm{C}$ for $18-24$ hours. From the plated results, the plates with the Colony Forming Unit (CFU) number between 30-300 were used in the determination of adhered bacteria [29]. In this study, the fourth serial dilution tube (T4) was found to correspond to this CFU numbers.

\section{Preparation of samples for scanning electron microscope (SEM) viewing}

The preparation of samples for SEM viewing was carried out according to the method described by Lagacé [et al. [30]. The glass beads with the biofilm formed on them were fixed in glutaraldehyde (4\%) in glass vials for one hour at room temperature. The glutaraldehyde was discarded and the glass beads were rinsed once with distilled water. The washed glass beads were then fixed in osmium tetraoxide (1\%) and left overnight (14 hours) in tightly capped vials at $4^{\circ} \mathrm{C}$ in the refrigerator. On the next day, the vials were taken out from refrigerator and left for 30 minutes at room temperature. The osmium tetraoxide (1\%) was gently pipetted out and the samples were washed with distilled water for 15 minutes. The dehydration process was carried out by treating the samples with the ascending percentages of ethanol (10\%-100\%). The samples were immersed in the different concentrations of ethanol for 15 minutes. The samples were then immersed in $100 \%$ ethanol twice to ensure that most of the water in the samples was eliminated. Gradual displacement of ethanol with acetone was then carried out (20 minutes each) using the following ratios (v/v): Ethanol: Acetone 3:1 1:1 1:3 Following that, the samples were immersed in $100 \%$ acetone for four times, 20 minutes each time, followed by Critical Point Dessication (CPD) process. The samples were then mounted on metal stubs and coated with gold. After gold-coating process, the samples were ready for SEM viewing.

\section{Statistical Analysis}

All data obtained in the study were analysed using t test of SPSS software. The values were expressed as mean \pm SD.

\section{Results}

From $100 \%$ bacterial inoculum pumped into the model, a singlespecies biofilm of Strep. mitis showed the maximum adherence (11.53\%) on the untreated experimental pellicle over a period of 24 hours, whereas only $1.83 \%$ of Strep. sanguinis adhered (Figure 6). The differences in the adherence capacity of these bacteria in the formation of the single-species biofilms were statistically significant $(\mathrm{p}<0.05)$. When the experimental pellicle was treated with plant extracts, the populations were significantly reduced for both streptococci. On the experimental pellicle treated with $0.12 \%$ chlorhexidine (CHX), it was observed that there was no adherence of Strep. sanguinis, while Strep. mitis showed slight adherence at $1.13 \%$. The population of Strep. sanguinis on the experimental pellicle treated with CHX was observed 
Citation: Wan Nordini Hasnor WI, Fathilah AR, Rahim ZHA (2013) Plant Extracts of Psidium guajava, Mangifera and Mentha sp. inhibit the Growth of the Population of Single-species Oral Biofilm. Altern Integ Med 2: 102. doi:10.4172/2327-5162.1000102

Page 4 of 6

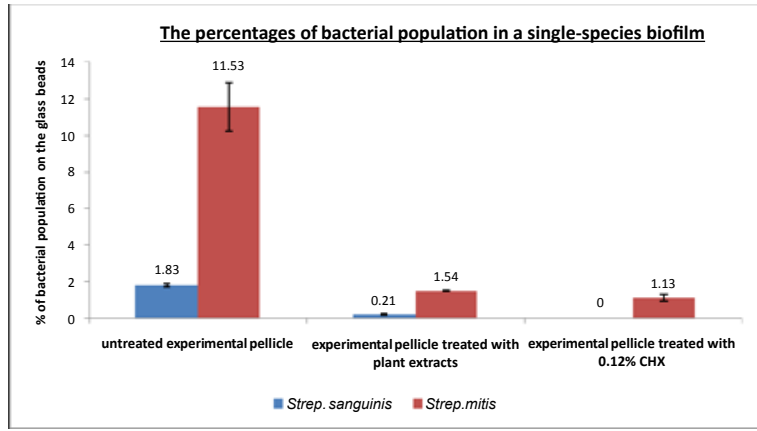

Figure 6: The histogram summarizing the bacterial population in the singlespecies biofilm of Strep. sanguinis and Strep. mitis on the (i) untreated experimental pellicle (negative-control), (ii) experimental pellicle treated with plant extracts, and (iii) experimental pellicle treated with $0.12 \% \mathrm{CHX}$ (positivecontrol). The values represent cells population adhering to the experimental pellicle. The values were expressed as means $\pm S D(N=18)$.
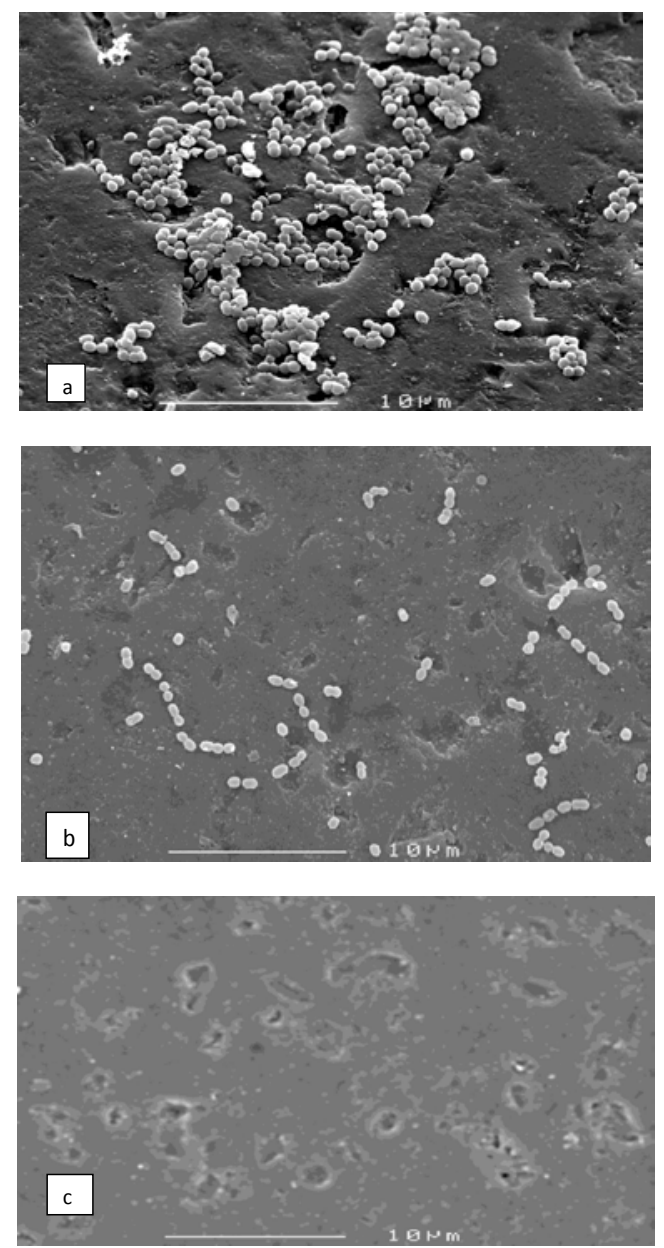

Figure 7: SEM micrographs showing populations of Strep. sanguinis in 24 hours biofilm on (a) untreated experimental pellicle, (b) experimental pellicle treated with plant extracts, and (c) experimental pellicle treated with $0.12 \%$ CHX. (3500X).

to be significantly less than their populations on the experimental pellicle treated with plant extracts $(\mathrm{p}<0.05)$. The population of Strep. mitis adhering on the experimental pellicle treated with CHX and plant extracts however showed no difference ( $p>0.05)$. This result was further confirmed by SEM viewing (Figures 7 and 8 ). It was clearly shown that population of Strep. sanguinis showed a moderate number of cells on the untreated experimental pellicle (Figure 7a). The cells tended to clump to each other. However, the population of Strep. sanguinis was decreased on the experimental pellicle treated with plant extracts (Figure $7 \mathrm{~b}$ ). The cells were also arranged in colonies of short chain consisted of two to three cells. On the experimental pellicle treated with $0.12 \% \mathrm{CHX}$, no cells were detected on the glass beads (Figure 7c).

The population of Strep. mitis showed a large number of cocci cells when they were allowed to grow on the untreated experimental pellicle (Figure 8a). The cells were clumped together. The numbers of cells were much reduced when the experimental pellicle was treated with plant extracts. Similar to Strep. sanguinis, the cells of Strep. mitis were also arranged in chains of colonies consisting of four to seven cells per chain (Figure $8 \mathrm{~b}$ ). On the experimental pellicle treated with $0.12 \% \mathrm{CHX}$, the number of cells adhered were almost similar to the cells that adhered on the experimental pellicle treated with plant extracts. However, only short chains were observed which consisted of two to four cells per chain (Figure 8c).
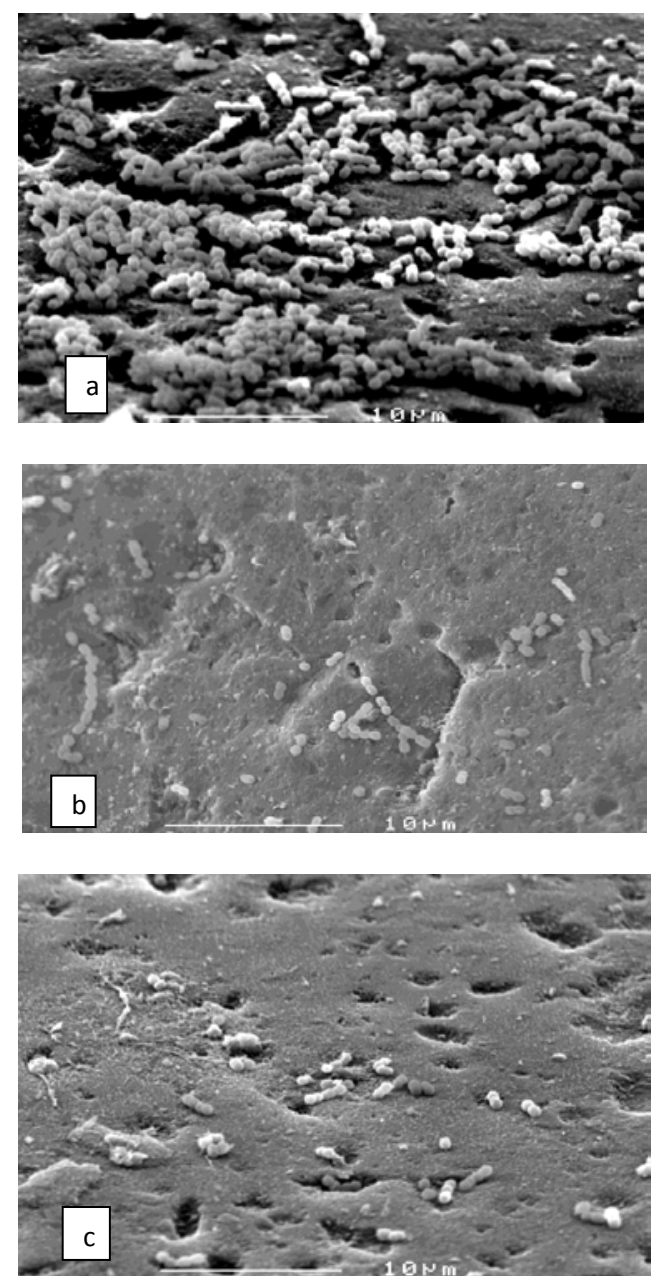

Figure 8: SEM micrographs showing populations of Strep. mitis in 24 hours biofilm on (a) untreated experimental pellicle, (b) experimental pellicle treated with plant extracts, and (c) experimental pellicle treated with $0.12 \% \mathrm{CHX}$ (3500X). 
Citation: Wan Nordini Hasnor WI, Fathilah AR, Rahim ZHA (2013) Plant Extracts of Psidium guajava, Mangifera and Mentha sp. inhibit the Growth of the Population of Single-species Oral Biofilm. Altern Integ Med 2: 102. doi:10.4172/2327-5162.1000102

Page 5 of 6

\section{Discussion}

Currently, there is an increasing interest to investigate the effect of natural compounds, especially plants extracts, on the residence of the oral cavity. Many of the investigations have been focused on the ability of the compound to either promote the growth of beneficial organisms or inhibit the growth and metabolism of oral bacteria associated with certain diseases. It has been reported that Morus alba [21], Andrographis paniculata and Chinese black tea [31], cranberry [32] and Mikania sp. [33] exhibited potentially useful antibacterial properties towards some oral pathogens. An alkaloid extract sanguinarine obtained from the plant Sanguinaria canadensis (bloodroot) is one example of natural based antimicrobials. The combined usage of mouthrinse and dentifrice containing sanguinarine has been shown to demonstrate the antiplaque effect [34-37] and also can be used to cure gingivitis [36,37].

Our study has shown that the extract of the leaves of Psidium sp., Mentha sp. and Mangifera sp. exhibited antimicrobial activities. The selection of these plants was based on findings that their extracts exhibited antimicrobial activities against oral microbes grown under the planktonic state [5]. The planktonic state refers to the condition where the bacteria were allowed to grow as suspension in the test tubes. It has been demonstrated in their studies that pre-treatment of experimental pellicle on saliva-coated glass beads with either $P$. guajava or Piper betle can significantly disrupt the adhesion of the early plaque colonizers to the pellicle. This subsequently will interfere with the initial stage of biofilm development. Similar observations have also been reported by Percival et al. [38] who strongly acknowledged the importance of the salivary pellicle during the initial stages of biofilm formation. The property of the pellicle can be altered in the presence of certain plant extracts. In a study carried out by Prashant et al. [39], positive antimicrobial activity of mango chewing stick was detected against oral Streptococci. The many positive antimicrobial activities on oral bacteria exhibited by plant extracts provide great support in the promotion of such extracts as oral healthcare agents. Their use may help to moderate the development of dental plaque so that its texture is always thin and porous. Besides, mouthwash sold in pharmacy stores or local supermarkets are either contains many chemicals or alcoholbased which may cause unwanted side effects to the consumers. On the untreated experimental pellicle, the adhesion affinity of the singlespecies biofilm of Strep. mitis is the highest (11.53\%) compared to those of Strep. sanguinis (1.83\%). The data obtained in this study however contradicted the findings reported by Fathilah [40] who reported that Strep. mitis and Strep. sanguinis, both showed almost similar percentage of adhesion affinities (22\%). The discrepancy in the results obtained in this study and Fathilah [40] might have been due to the state of cells used in the experiment. In our study, the bacteria cells and the nutrients were continuously supplied to the growth system of the artificial mouth (NAM) model. On the contrary in the planktonic state, bacteria cells were grown under a static phase [40]. In a condition when there was no flow of nutrients involved, the cells in the planktonic state may have the ability to adhere at a greater extent than cells growing in a continuous system [41]. Under this state, cells were more exposed to the clearing effect of the flowing liquid. Significant differences with respect to the growth of cells while under the planktonic and biofilm condition have also been reported by Black et al. [42] and Ceri et al. [43].

When the experimental pellicle was treated with plant extracts, it was clearly shown in the results that the number of adhering cells in the single-species biofilm was reduced. This is because the binding of bacterial cells to the acquired pellicle in the mouth or to the experimental pellicle in vitro is much influenced by the adherence capacity of the pellicle. Once the experimental pellicle was altered by plant extracts or any other antimicrobial agent, it will affect the binding affinity of the bacteria. Our results are consistent with the study carried out by Oliveira et al. [44], which confirmed the antimicrobial effects of plant's components to the single-species oral biofilm. Throughout the studies, CHX was chosen as a positive-control as it is the most widely used chemotherapeutic agent and known for its ability to inhibit plaque and gingivitis [44-48]. CHX has been vastly used in the prevention of dental caries especially in patients following radiation therapy who often have difficulty in performing tooth brushing $[49,50]$. The mechanism of action of CHX has been associated with its effect on pellicle formation [51], bacterial adherence mechanisms as well as modification of the bacterial cell wall properties which ultimately will cause lysis of the cell [52]. From SEM results, we are suggesting that the mechanism of action of mixed-plant extracts used in this study might be towards the formation of experimental pellicle. Once this pellicle was disrupted, the pioneer bacteria in the oral cavity like Strep. mitis and Strep. sanguinis could not adhere to the tooth surfaces. However, further study need to be done to investigate more on this matter.

\section{Conclusion}

The plant extract applied to the saliva-coated glass beads appeared to have altered the experimental pellicle and subsequently reduced the adhesion affinity of the bacteria in the biofilms. This may suggest that the extracts of the plants have potential as anti-plaque agents.

\section{Acknowledgement}

This study was supported by Vote F0145/2005A, R\&D IRPA No 09-02-030197 EA197 \& Kuok Foundation Bhd. 13.

\section{References}

1. Ahmad F, Raji H (1993) Chemistry of Natural Products and Medicinal Plants New York: John Wiley and Sons.

2. Zakaria M, Mohamad MA (1992) Plants and Traditional Perubatan. Kuala Lumpur: Fajar Bakti Sdn Bhd

3. Jaiarj $P$, Khoohaswan $P$, Wongkrajang $Y$, Peungvicha $P$, Suriyawong $P$, et al (1999) Anticough and antimicrobial activities of Psidium guajava Linn. leaf extract. J Ethnopharmacol 67: 203-212.

4. Abdelrahim SI, Almagboul AZ, Omer ME, Elegami A (2002) Antimicrobia activity of Psidium guajava L. Fitoterapia 73: 713-715.

5. Razak FA, Rahim ZH (2003) The anti-adherence effect of Piper betle and Psidium guajava extracts on the adhesion of early settlers in dental plaque to saliva-coated glass surfaces. J Oral Sci 45: 201-206

6. Razak FA, Othman RY, Rahim ZH (2006) The effect of Piper betle and Psidium guajava extracts on the cell-surface hydrophobicity of selected early settlers of dental plaque. J Oral Sci 48: 71-75.

7. Kabuki T, Nakajima H, Arai M, Ueda S, Kuwabara Y, et al. (2000) Characterization of novel antimicrobial compounds from mango (Mangifera indica L.) kernel seeds. Food Chemistry 71: 61-66

8. Handley PS, McNab R, Jenkinson HF (1999) Adhesive surface structures on oral bacteria. United Kingdom: BioLine 145-170.

9. Samaranayake LP (2002) Essential Microbiology for Dentistry (2ndedn) Edinburgh: Churchill Livingstone 207-216.

10. Maiden MFJ, Lai CH, Tanner A (1992) Characteristics of oral gram-positive species. St Louis: Mosby Year Book 342-372.

11. Caufield PW, Dasanayake AP, Li Y, Pan Y, Hsu J, et al. (2000) Natural history of Streptococcus sanguinis in the oral cavity of infants: evidence for a discrete window of infectivity. Infect Immun 68: 4018-4023.

12. Lucas VS, Beighton D, Roberts GJ (2000) Composition of the oral streptococcal flora in healthy children. J Dent 28: 45-50.

13. Costerton JW, Cook G, Lamont R (1999) The community architecture of biofilms: Dynamics structure and mechanisms. United Kingdom: BioLine 5-14. 
Citation: Wan Nordini Hasnor WI, Fathilah AR, Rahim ZHA (2013) Plant Extracts of Psidium guajava, Mangifera and Mentha sp. inhibit the Growth of the Population of Single-species Oral Biofilm. Altern Integ Med 2: 102. doi:10.4172/2327-5162.1000102

14. Marsh PD, Martin MV (1999) Oral Microbiology (4thedn), Great Britain: Wright.

15. Sutherland IW (2001) The biofilm matrix-an immobilized but dynamic microbial environment. Trends Microbiol 9: 222-227.

16. Sutherland IW (1999) Biofilm matrix polymers-Role in adhesion. United Kingdom: BioLine 49-62.

17. KiranÇ M (1997) Antimicrobial activity of fresh plant juice on the growth of bacteria and yeasts. Journal of Qafqaz University.

18. Fathilah AR, Bakri MM, Rahim ZHA (2000) Effects of crude water extracts of local plants on selected plaque microorganisms. Proceedings of the $3 \mathrm{rd}$ National Health Sciences Symposium..

19. Nalina T, Hasnah SGK, Rahim ZHA (2001) Antimicrobial activities and HPLC profiles of the crude extracts of clove. Proceedings RMK7 IRPA Research Seminar 1: 501-504.

20. Arima H, Danno G (2002) Isolation of antimicrobial compounds from guava (Psidium guajava L.) and their structural elucidation. Biosci Biotechnol Biochem 66: 1727-1730.

21. Park KM, You JS, Lee HY, Baek NI, Hwang JK (2003) Kuwanon G: an antibacterial agent from the root bark of Morus alba against oral pathogens. J Ethnopharmacol 84: 181-185

22. Takarada K, Kimizuka R, Takahashi N, Honma K, Okuda K, et al. (2004) A comparison of the antibacterial efficacies of essential oils against oral pathogens. Oral Microbiol Immunol 19: 61-64.

23. Filoche SK, Soma K, Sissons CH (2005) Antimicrobial effects of essential oils in combination with chlorhexidine digluconate. Oral Microbiol Immunol 20: 221225

24. Wong L, Sissons C (2001) A comparison of human dental plaque microcosm biofilms grown in an undefined medium and a chemically defined artificial saliva. Arch Oral Biol 46: 477-486.

25. Alves TM, Silva AF, Brandão M, Grandi TS, Smânia E, et al. (2000) Biological screening of Brazilian medicinal plants. Mem Inst Oswaldo Cruz 95: 367-373.

26. Rahim ZHA, Fathilah AR, Irwan S, Wan Nordini Hasnor WI (2008) An Artificial Mouth System (NAM Model) for Oral Biofilm Research. Research Journal of Microbiology 3: 466-473.

27. De Jong MH, Van der Hoeven JS (1987) The growth of oral bacteria on saliva J Dent Res 66: 498-505.

28. Wan Nordini Hasnor WI, Fathilah AR, Yusoff MM, Rahim ZHA (2008) The Behaviour of Selected Oral Bacteria in Single- and Mixed-Species Biofilms. Journal of Biological Sciences 8: 1001-1007.

29. Benson HJ (2002) Microbiological Applications: Laboratory manual in general microbiology (8thedn), Boston: McGraw-Hill Higher Education.

30. Lagacé L, Jacques M, Mafu AA, Roy D (2006) Compositions of maple sap microflora and collection system biofilms evaluated by scanning electron microscopy and denaturing gradient gel electrophoresis. Int J Food Microbiol 109: 9-18.

31. Limsong J, Benjavongkulchai E, Kuvatanasuchati J (2004) Inhibitory effect of some herbal extracts on adherence of Streptococcus mutans. J Ethnopharmacol 92: 281-289.

32. Yamanaka A, Kimizuka R, Kato T, Okuda K (2004) Inhibitory effects of cranberry juice on attachment of oral streptococci and biofilm formation. Oral Microbiol Immunol 19: 150-154.

33. Yatsuda R, Rosalen PL, Cury JA, Murata RM, Rehder VL, et al. (2005) Effects of Mikania genus plants on growth and cell adherence of mutans streptococci. J Ethnopharmacol 97: 183-189.

34. Kopczyk RA, Abrams H, Brown AT, Matheny JL, Kaplan AL (1991) Clinical and microbiological effects of a sanguinaria-containing mouthrinse and dentifrice with and without fluoride during 6 months of use. J Periodontol 62: 617-622.

35. Harper DS, Mueller LJ, Fine JB, Gordon J, Laster LL (1990) Effect of 6 months use of a dentifrice and oral rinse containing sanguinaria extract and zinc chloride upon the microflora of the dental plaque and oral soft tissues. $J$ Periodontol 61: 359-363.
36. Wennström J, Lindhe J (1985) Some effects of a Sanguinarine-containing mouthrinse on developing plaque and gingivitis. J Clin Periodontol 12: 867-872.

37. Klewansky P, Vernier D (1984) Sanguinarine and the control of plaque in dental practice. Compend Contin Educ Dent : S94-S97.

38. Percival RS, Devine DA, Duggal MS, Chartron S, Marsh PD (2006) The effect of cocoa polyphenols on the growth, metabolism, and biofilm formation by Streptococcus mutans and Streptococcus sanguinis. Eur J Oral Sci 114: 343348.

39. Prashant GM, Chandu GN, Murulikrishna KS, Shafiulla MD (2007) The effect of mango and neem extract on four organisms causing dental caries: Streptococcus mutans, Streptococcus salivarius, Streptococcus mitis and Streptococcus sanguis: An in-vitro study. Indian Journal of Dental Research 18: $148-151$.

40. Fathilah AR (2004) An in vitro study on the potential antiplaque effects of Piper betle and Psidium guajava. Faculty of Dentistry: University of Malaya.

41. Flohr H, Breull W (1975) Effect of etafenone on total and regional myocardial blood flow. Arzneimittelforschung 25: 1400-1403.

42. Black C, Allan I, Ford SK, Wilson M, McNab R (2004) Biofilm-specific surface properties and protein expression in oral Streptococcus sanguis. Arch Oral Bio 49: 295-304.

43. Ceri H, Olson ME, Stremick C, Read RR, Morck D, et al. (1999) The Calgary Biofilm Device: new technology for rapid determination of antibiotic susceptibilities of bacterial biofilms. J Clin Microbiol 37: 1771-1776.

44. Oliveira MR, Napimoga MH, Cogo K, Gonçalves RB, Macedo ML, et al. (2007) Inhibition of bacterial adherence to saliva-coated through plant lectins. J Ora Sci 49: 141-145.

45. Briner W, Buckner R, Rebitski G, Manhart M, Banting D (1989) Effect of two years' use of $0.12 \%$ chlorhexidine on plaque bacteria. Journal of Dental Research 68: 1719-1721.

46. Netuschil L, Reich E, Brecx M (1989) Direct measurement of the bactericidal effect of chlorhexidine on human dental plaque. J Clin Periodontol 16: 484-488.

47. Brecx M, Netuschil L, Reichert B, Schreil G (1990) Efficacy of Listerine, Merido and chlorhexidine mouthrinses on plaque, gingivitis and plaque bacteria vitality. J Clin Periodontol 17: 292-297.

48. Rundegren J, Hvid EB, Johansson M, Aström M (1992) Effect of 4 days of mouth rinsing with delmopinol or chlorhexidine on the vitality of plaque bacteria. J Clin Periodontol 19: 322-325.

49. Arweiler NB, Donos N, Netuschil L, Reich E, Sculean A (2000) Clinical and antibacterial effect of tea tree oil--a pilot study. Clin Oral Investig 4: 70-73.

50. Epstein JB, Loh R, Stevenson-Moore P, McBride BC, Spinelli J (1989) Chlorhexidine rinse in prevention of dental caries in patients following radiation therapy. Oral Surg Oral Med Oral Pathol 68: 401-405.

51. Guan YH, Lath DL, Graaf T, Lilley TH, Brook AH (2003) Moderation of oral bacterial adhesion on saliva-coated hydroxyapatite by polyaspartate. J App Microbiol 94: 456-461.

52. Fiorellini JP, Paquette DW (1992) The potential role of controlled-release delivery systems for chemotherapeutic agents in periodontics. Curr Opin Dent 2: 63-79. 